\title{
Teaching NeuroImages: Magnetic Susceptibility-Weighted Imaging Mapped the Migratory Route of a Paragonimus in Brain
}

Ke Yu, MD, and Mingjie Zhang, MD

Neurology ${ }^{\circledR}$ 2021;96:e2351-e2352. doi:10.1212/WNL.0000000000011492

Figure 1 Paragonimus Egg and Tunnel Sign
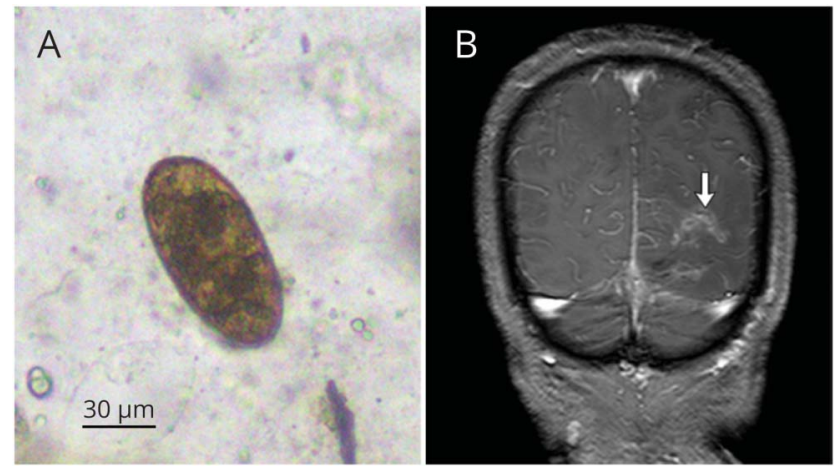

(A) A brown oval paragonimus egg on sputum microscopy. (B) Coronal enhanced T1-weighted MRI shows the tunnel sign appearing as a hollow tube lesion (arrow).

A 53-year-old man with a recent history of left temporal lobe hemorrhage presented with weakness of the left upper limb for 4 days. Paragonimus eggs were detected in the patient's sputum (figure 1A). Workup revealed paragonimiasis, a lung flukeworm infection endemic to

Figure 2 Magnetic Susceptibility-Weighted Imaging (SWI) Mapped the Paragonimus Track in Brain
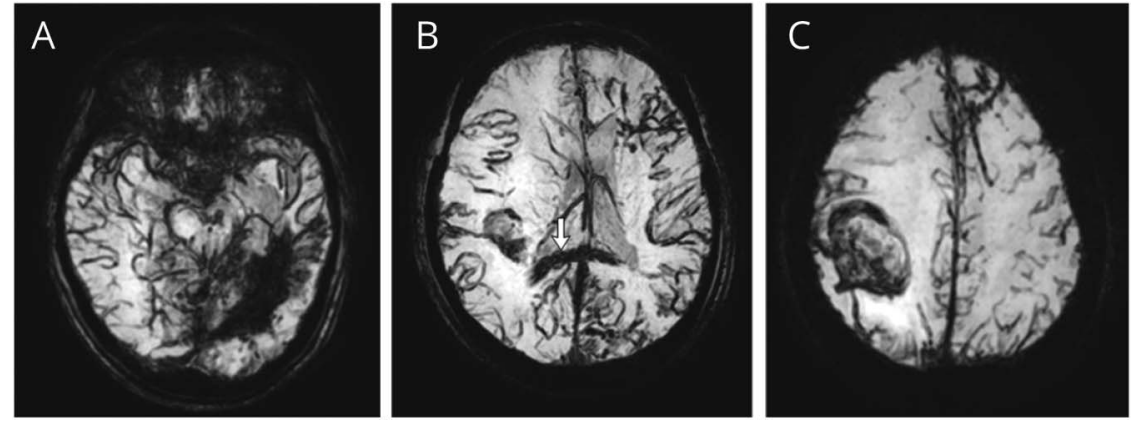

(A) SWI shows a patchy hemorrhagic focus in the left temporal lobe. (B) SWI reveals a crescentic hypointense signal in the splenium of the corpus callosum (arrow), representing the left to right migratory track of the worm. (C) SWI demonstrates a cystic heterogeneous lesion in the right parietal lobe.
Correspondence

Dr. Yu

yuke909@126.com

\section{MORE ONLINE}

$\rightarrow$ Teaching slides

links.lww.com/WNL/

B315

From the Department of Neurology, The General Hospital of Western Theater Command, Chengdu, China.

Go to Neurology.org/N for full disclosures. Funding information and disclosures deemed relevant by the authors, if any, are provided at the end of the article. 
East Africa, West Africa, and South America, which rarely involves brain. ${ }^{1}$ Characteristic tunnel sign was visualized on brain MRI (figure 1B). Notably, susceptibility-weighted imaging revealed a migratory pattern of the parasite from the left temporal lobe to the right parietal lobe and resultant patchy hemorrhage (figure 2). Treatment with praziquantel resulted in favorable outcome without residual deficits.

\section{Study Funding}

No targeted funding reported.

\section{Disclosure}

The authors report no disclosures relevant to the manuscript. Go to Neurology.org/ $\mathrm{N}$ for full disclosures.

\section{Appendix Authors}

\begin{tabular}{lll}
\hline Name & Location & Contribution \\
\hline $\begin{array}{l}\text { Ke Yu, } \\
\text { MD }\end{array}$ & $\begin{array}{l}\text { Department of Neurology, The } \\
\text { General Hospital of Western } \\
\text { Theater Command, Chengdu, } \\
\text { China }\end{array}$ & $\begin{array}{l}\text { Data collection, drafting } \\
\text { and revising the } \\
\text { manuscript }\end{array}$ \\
\hline $\begin{array}{l}\text { Mingjie } \\
\text { Zhang, }\end{array}$ & $\begin{array}{l}\text { Department of Neurology, The } \\
\text { General Hospital of Western } \\
\text { Theater Command, Chengdu, } \\
\text { China }\end{array}$ & $\begin{array}{l}\text { Editing figures and } \\
\text { revising the manuscript }\end{array}$ \\
&
\end{tabular}

\section{Reference}

1. Xia Y, Chen J, Ju Y, You C. Characteristic CT and MR imaging findings of cerebral paragonimiasis. J Neuroradiol 2016;43:200-206. 


\section{Neurology}

\section{Teaching NeuroImages: Magnetic Susceptibility-Weighted Imaging Mapped the Migratory Route of a Paragonimus in Brain $\mathrm{Ke} \mathrm{Yu}$ and Mingjie Zhang}

Neurology 2021;96;e2351-e2352 Published Online before print January 13, 2021

DOI 10.1212/WNL.0000000000011492

This information is current as of January 13, 2021

\section{Updated Information \&} Services

References

Subspecialty Collections

Permissions \& Licensing

Reprints including high resolution figures, can be found at: http://n.neurology.org/content/96/18/e2351.full

This article cites 1 articles, 0 of which you can access for free at: http://n.neurology.org/content/96/18/e2351.full\#ref-list-1

This article, along with others on similar topics, appears in the following collection(s):

All Clinical Neurology

http://n.neurology.org/cgi/collection/all_clinical_neurology

MRI

http://n.neurology.org/cgi/collection/mri

Parasitic infections

http://n.neurology.org/cgi/collection/parasitic_infections

Information about reproducing this article in parts (figures,tables) or in its entirety can be found online at:

http://www.neurology.org/about/about_the_journal\#permissions

Information about ordering reprints can be found online:

http://n.neurology.org/subscribers/advertise

Neurology ${ }^{\circledR}$ is the official journal of the American Academy of Neurology. Published continuously since 1951, it is now a weekly with 48 issues per year. Copyright @ 2021 American Academy of Neurology. All rights reserved. Print ISSN: 0028-3878. Online ISSN: 1526-632X.

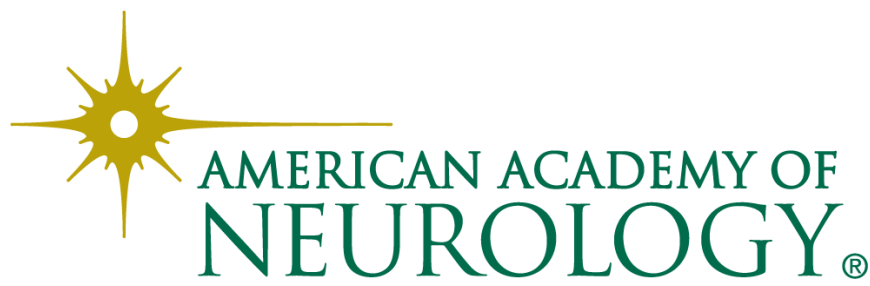

